\title{
The performance of breeders' groups in supporting the increase in the beef cattle population in Barru district, Barru Regency, South Sulawesi Province
}

\author{
Daeva Mubarika Raisa1, Sitti Nurani Sirajuddin², Agustina Abdullah³ , Didi Rukmana², Rahim Darma², \\ Aslina Asnawi ${ }^{3}$ \\ ${ }^{1}$ Agribusiness Study Program Students, Postgraduate School of Hasanuddin University, Makassar. 90245, Indonesia. \\ ${ }^{2}$ Lecturer of Agribusiness Program, Postgraduate School of Hasanuddin University, Makassar. 90245, Indonesia. \\ ${ }^{3}$ Lecturer of Social Economic Departement of Animal Husbandry Faculty of Hasanuddin University, Makassar. 90245, Indonesia.
}

Correspondence Author: Daeva Mubarika Raisa, Agribusiness Study Program Students, Postgraduate School of Hasanuddin University

Email: daevamubarikaraisa@ pasca.unhas.ac.id

Received date: 28 August 2019, Accepted date: 2 December 2019, Online date: 20 December 2019

Copyright: (C) 2019 Daeva Mubarika Raisa et al., This is an open-access article distributed under the terms of the Creative Commons Attribution License, which permits unrestricted use, distribution, and reproduction in any medium, provided the original author and source are credited.

\begin{abstract}
This study discusses increasing livestock farmer groups, in order to increase groups, increase ability classes, and improve agricultural development in Barru District, Barru District, South Sulawesi Province. The selection of research sites based on data from the Agriculture Department of Barru Regency said that this Subdistrict had a group that had ability classes with a number of beginner groups of 14 groups. The study was conducted from Juni to July 2019. The population of this study were all members of farmer groups in the District of Barru, District of Barru in the ability class of the Beginner group supported by 402 farmers. Determination of the sample is calculated based on the Slovin formula with a sample size of 38 farmers. The results showed an average level of appropriateness between the farmer groups and the Beginner class in Barru District was 40.27, an increase in the support of group capacity development using further IPA analysis of the attributes in the quadrant. Through the IPA analysis it can be seen the CSI results which state the level of member satisfaction is at an interval of 34 percent or 0.34 . This value is not maximal or in the category of "dissatisfied" livestock farmers must continue to improve their performance.
\end{abstract}

Keywords: Performance, Livestock farmer groups, Increased class ability, Increasing beef cattle population.

\section{INTRODUCTION}

Food sovereignty is becoming increasingly relevant as Indonesia has entered the era of free trade, including the Asean Economic Community (AEC). The government has now designed to make Indonesia a world food barn, focusing on food commodities such as rice, corn, soy beans, shallots, garlic, chili, sugar and beef.

With the high increase in beef consumption in Indonesia. In some ASEAN countries now prefer Indonesian beef; this has led to the development of beef cattle business policy has a bright future. Livestock as one of the agricultural sub-sectors is an integral part of the success of this sector in Indonesia to achieve development goals. Efforts to raise beef cattle are efforts to increase beef productivity as optimal as possible in order to increase the availability of beef in Indonesia [1].

Basing on the orientation of agricultural development in Indonesia today which is based on the agribusiness system, is the role of agricultural institutions, including farmer institutions which determine the success of agricultural development. Farmer institutions in rural areas contribute to the acceleration of farmers' socioeconomic development, accessibility to agricultural information, accessibility to capital, infrastructure, markets and adoption of agricultural innovations. Also, the existence of farmer institutions will make it easier for the government and other stakeholders to facilitate and provide strengthening to farmers [2]. This condition resulted in many institutions involved to deal with. Institutional support for groups is needed and the participation of supporting institutions greatly influences the progress of agribusiness.

The development of beef cattle production from 2013 to 2018 shows an increase, this shows that the dynamics of livestock population is determined by the balance between birth rates, deaths, slaughtering, income and expenditure of livestock in a region [3]. The dynamics or increase in beef cattle population in Barru Regency over the past 5 years (2013-2018) increased by 
Citation: Daeva Mubarika Raisa., 2019. The performance of breeders' groups in supporting the increase in the beef cattle population in Barru district, Barru Regency, South Sulawesi Province. Advances in Environmental Biology., 13(12): 77-82. DOI:10.22587/aeb.2019.13.12.14

an average of $0.91 \%$. And beef production shows a tendency to increase every year, which is very influential in the development of animal husbandry agribusiness. However, this has not been able to meet the needs of beef consumption so as to meet those needs, the import is done. To reduce beef imports, this can be increased through the encouragement of beef cattle breeding to increase births, IB policies need to be improved, productive female cows to be slaughtered secured by government purchases for breeding activities, and increased breeders' ability through group institutions. [4] To face challenges in farmer groups, an effective approach is needed so that group members can interact with each other. This can lead to improved performance in terms of knowledge and management in the livestock business and can encourage groups in the development of the beef cattle business.

The farmer's characteristics (age, educational level, farming experience, not related to the choice of adaptation strategy, while the number of family dependents and role of advisor was associated with the option of adaptation strategy. [5] Access cooperative farmers and extension agents can increase the productivity of farmers. [6] Method of participatory training intervention through learning by the doing method can become an economics machine for improvement of farmer's income. [7] The implication was local government especially should give more extension to farmers. [8]

For this reason, livestock farmer group institutions need to be fostered and empowered so that they become a solid group that can access agricultural development facilities. Thus, to answer the above problems, a study was carried out to see what needed to be improved so that the group could own the performance of Farmer groups in the Beginner ability class to improve group functions, increase ability classes, and increase agricultural development in increasing beef cattle populations.

\section{RESEARCH METHODS}

This research was conducted in Barru Regency, Barru Regency, South Sulawesi Province. The selection of research locations is based on data from the Department of Agriculture of Barru Regency that the Regency has a group that has the ability class with the greatest number of advanced groups, namely 14 groups. The study was conducted from June to July 2019. The population of this study was all members of the livestock farmer groups in Barru Regency, Barru Regency in the ability group of Beginner groups, totaling 402 farmers. The determination of the sample is calculated based on the Slovin formula with a sample of 38 farmers. Research data were collected using data collection techniques. Namely, interviews, focus group discussions (FGD) by conducting focus group discussions, as well as conducting in-depth interviews with key informants namely extension officers and leaders of farmer/livestock groups in Barru District, Barru District, South Sulawesi. The data obtained were analyzed using data analysis about the Importance Performance Analysis (IPA) and Customer Satisfaction Index (CSI). This analysis is used to overcome problems regarding the level of satisfaction of farmers/farmers with services from existing institutions, then plotted into the Cartesian diagram [9] and CSI values.

\section{RESULTS AND DISCUSSION}

1. Importance Performance Analysis (IPA)

Based on the results of the calculation of the IPA analysis the TKI obtained in Table 1 was obtained with an average value of the institutional suitability level of the farmer-livestock groups for the ability of beginner groups of 40.27 , which can be seen in the following table:

Table 1: Results of an average calculation of the level of importance and performance for institutional farmer groups

\begin{tabular}{|c|c|c|c|c|}
\hline \multirow{2}{*}{\multicolumn{2}{|c|}{ Service aspects (attributes) }} & \multicolumn{3}{|c|}{$\begin{array}{c}\text { Animal Farmer } \\
\text { Group } \\
\text { Institutions }\end{array}$} \\
\hline & & $(x)$ & $T(y)$ & $=\mathbf{T K i}$ \\
\hline \multicolumn{5}{|c|}{$\begin{array}{l}\text { A. Strengthening livestock farmer groups into institutions } \\
\text { strong and independent }\end{array}$} \\
\hline 1 & Hold regular meetings & $\mid 1,60$ & 4,20 & 3,10 \\
\hline 2 & Prepare RDK and RDKK work plans & 2,68 & 4,50 & 59,56 \\
\hline 3 & Facilitating joint business activities in the upstream to downstream sectors & 1,30 & 3,47 & 37,46 \\
\hline 4 & Facilitating commercial and market-oriented farming & 1,80 & 3,43 & 52,48 \\
\hline \multicolumn{5}{|c|}{ B. Increasing the ability of members in the development of farming } \\
\hline 5 & Streamlining the process of identifying needs and problems in farming & 1,53 & 4,25 & 36,00 \\
\hline 6 & Improve the ability of members & 1,50 & 4,43 & 33,86 \\
\hline 7 & Development of creativity and member initiatives & 1,15 & 4,25 & 27,06 \\
\hline 8 & Developing the ability of members to produce technology & 1,47 & 4,73 & 31,08 \\
\hline \multicolumn{5}{|c|}{$\begin{array}{l}\text { C. Increasing the ability of farmer groups } \\
\text { in implement functions }\end{array}$} \\
\hline & 1. Learning Class & & & \\
\hline 9 & Foster discipline and motivation of members; & 2,00 & 4,63 & 43,20 \\
\hline 10 & Conducting meetings and learning in a conducive and orderly manner & 1,15 & 4,25 & 27,06 \\
\hline 11 & $\begin{array}{l}\text { Establish cooperation with information sources in the teaching and learning process, both from fellow } \\
\text { members, advisory agencies and related parties }\end{array}$ & 1,93 & 4,10 & 47,07 \\
\hline 12 & $\begin{array}{c}\text { Active in the teaching-learning process, including bringing in and consulting agricultural extension } \\
\text { institutions, and other sources of information }\end{array}$ & 1,90 & 4,17 & 45,56 \\
\hline
\end{tabular}


Citation: Daeva Mubarika Raisa., 2019. The performance of breeders' groups in supporting the increase in the beef cattle population in Barru district, Barru Regency, South Sulawesi Province. Advances in Environmental Biology., 13(12): 77-82. DOI:10.22587/aeb.2019.13.12.14

\begin{tabular}{|c|c|c|c|c|}
\hline 13 & Formulating collective agreements, in solving problems and carrying out various activities & 1,10 & 4,57 & 24,07 \\
\hline \multicolumn{5}{|c|}{$\begin{array}{ll} & \text { Forum for Cooperation } \\
\end{array}$} \\
\hline 14 & $\begin{array}{c}\text { Organize and carry out the division of tasks / work between members in accordance with mutual } \\
\text { agreement }\end{array}$ & 1,53 & 4,25 & 42,86 \\
\hline 15 & Develop discipline and a sense of responsibility among members & 1,44 & 4,25 & 33,88 \\
\hline 16 & Implement deliberations to reach an agreement that is beneficial for members & 1,20 & 4,57 & 26,26 \\
\hline 17 & $\begin{array}{c}\text { Establish cooperation / business partnerships with providers of production, processing, marketing of results } \\
\text { and / or capital }\end{array}$ & 1,85 & 4,20 & 44,05 \\
\hline \multicolumn{5}{|c|}{ 3. Production Unit } \\
\hline & Facilitating the application of technology (materials, tools, ways) Farming by members by the activity plan & 1,70 & 3,63 & 46,83 \\
\hline 19 & Administrative management is good and right & 3,40 & 4,50 & 75.56 \\
\hline 20 & Ability to plan the processing and marketing of results & 1,70 & 4,23 & 117,83 \\
\hline & Average & $\mathbf{1 , 7 0}$ & 4,23 & 40,27 \\
\hline
\end{tabular}

Source: Primary Data After Processing in 2019

Based on Table 28 it can be seen that the average value of importance is 4.23 and the average value of performance is 1.70 . These two values will be the centerline in the Cartesian Importance Performance Analysis (IPA) diagram, where the importance level as the $\mathrm{Y}$-axis and the performance level as the X-axis. The Cartesian Importance Performance Analysis (IPA) diagram can be seen in Figure 1.

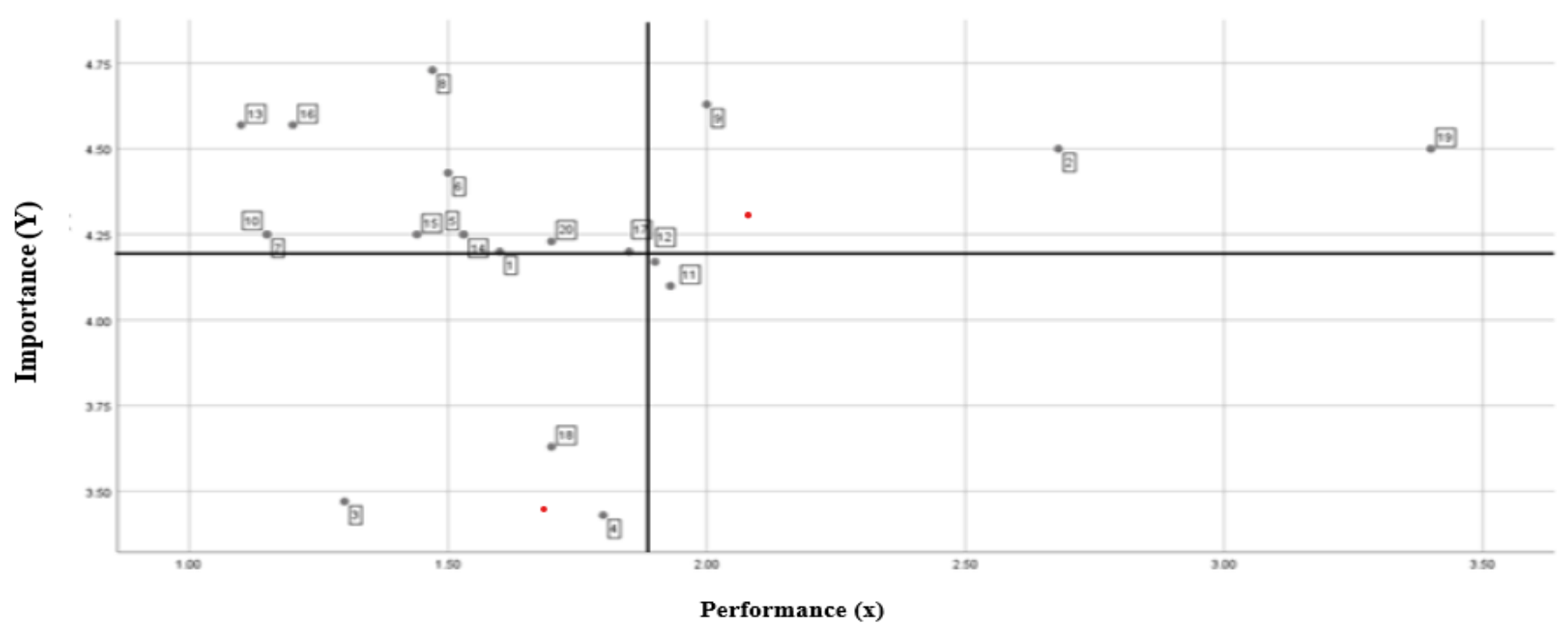

Figure 1. Cartesian Importance Performance Analysis (IPA) Diagram in a beginner group ability class

Figure 1 can be explained that the mapping on the Cartesian diagram based on the level of importance and level of performance allows groups of beef cattle farmers to make improvements to attributes that are considered relevant by groups of farmers, both in the short term and in the long term. With the development of characteristics, it can be more comfortable for breeders to prioritize improvements over each attribute. Attribute improvement is very dependent on the position of each variable in the four quadrants.

The calculation results show quadrant I on the Cartesian diagram shows a quadrant that describes the attributes of the ability of the group as attributes that are important to members, but its performance is not yet optimal. The performance of this attribute must be made a top priority in the BEGINNERS 'group's ability to be further improved for the future sustainability of the group. The characteristics entered in quadrant I am as follows:

a. Hold regular meetings

In-depth interviews with farmer group organizers and extension workers showed that farmer groups in Barru sub-district felt the importance of strengthening farmer-livestock groups to become strong and independent institutions but still not in line with expectations, livestock farmer groups could not play a role in group activities, and the low role and function of farmer group management. With the low effectiveness of roles and functions of livestock farmer groups, the group performance is low. As well as instructors who served in Barru District Barru Regency stated that the low level of performance was due to lack of cohesiveness due to the low level of meetings, as well as lack of information from members of the group management. b. Streamlining the process of identifying needs and problems in farming

Planning activities in a livestock group business that has not been neatly arranged and organized by the group administrator is a group obstacle that is considered to be a poor performance by members. This affects the smooth running of the member farms. Not infrequently as a result of business planning that has not been neatly arranged, group members find it difficult to meet the demand for beef cattle and livestock business waste from consumers when demand is excessive. This condition is because the group, especially the management, does not have a database of each member regarding the ability of members to produce an increase in the population of beef cattle as well as the results of the treatment of livestock waste.

c. Development of creativity and initiative of members, Increasing the ability of members 
Creativity and initiative of members through training and education have never been done in some groups with beginner ability classes, even though this is felt by members is very important. This makes the group's performance on this attribute also still low considering training in developing the creativity of members needs to be done in order to improve the ability of group members and improve their welfare.

d. Development of the ability of members to produce technology

Developing the ability to create technology has performance that must be improved so that this can be by encouraging healthy competence from group members to develop and use technology such as biogas production, utilization of livestock business waste in order to add economic value.

e. Conduct meetings and learning in a conducive and orderly manner

Conducive and orderly meetings and learning activities in farming activities have a performance with top priority to be improved, this is because the majority of group members work in agriculture and their livestock business is only a side business. So it is less enthusiastic in meetings and counseling that causes the social level of livestock farmer groups to accept new innovations.

f. Formulating collective agreements, in solving problems and carrying out various activities

g. Organize and carry out the division of tasks/work between members in accordance with mutual agreement

In this attribute, the performance in the group becomes the main priority to be improved because in group meetings held to produce mutual agreement and solve problems, group members still have several factors so that they have not been able to solve group problems. This is due to a lack of motivation, wrong beliefs and attitudes, habits, and emotions in expressing opinions.

h. Carry out deliberations to reach an agreement that is beneficial for members

The lack of regular meetings causes members to evaluate the role of management in managing groups that are not active and integrated. Evaluation by conducting deliberations is expected to know the needs of individuals both in their farming and animal husbandry business, so this attribute needs to be improved.

i. Establish cooperation/business partnerships with providers of production, processing, marketing of products and/or capital. This attribute is a priority that needs to be improved because partnerships can improve technical aspects, economic aspects, and social aspects in the group.

j. Develop discipline and a sense of responsibility among members

Lack of willingness and ability of members and management to continue the management caused delays in the planned program. At present many group administrators are concurrently chairing other divisional divisions, as well as busy in other jobs. So that there is an imbalance in the discipline of group management, but members do not respond seriously. Although the members consider this very important, there is no further action from both the administration and members.

k. Ability to plan the processing and marketing of results

Products produced in the livestock business are in the form of breeding cows, feeder cattle, and cattle ready for slaughter. In general, breeders sell calves at the age of $<1$ year, with consideration of immediately providing income. However, it can also be detrimental to farmers because if it is seen from the added value generated it has not reached an optimal level.

The attributes in quadrant II describe the attributes of the group's abilities as attributes that are considered very important by members and have been implemented by farmer group organizations well according to the expectations of group members. The group must maintain performance in this attribute because this attribute is the strength of the group in maintaining the members' trust in the group's organizational performance. The attributes included in quadrant II are a. Prepare RDK and RDKK plans

Each year the RDK / RDKK program is prepared through assistance by agricultural instructors in each village / kelurahan. b. Cultivate member motivation

Some members have high motivation in joining livestock farmer groups, with the needs to be achieved through the group, and the desired expectations after joining the group, as well as the needs to be met such as getting livestock farming assistance in the form of seedlings, fertilizers, medicines, and livestock vaccinations. And hope is to increase income, knowledge, attitudes, and skills in farming.

c. Good and correct administration management

The administration of livestock farmer groups in Barru Subdistrict went well, in addition, the influence of PPL made improvements to the management of group administration.

The attributes that are in quadrant III describe the attributes of the aspects of the ability of groups as less critical attributes and the actual performance is also still low The attributes included in quadrant III are:

a. Facilitating joint business activities in the upstream to downstream sectors

In the source of business, capital assistance is still lacking, becoming one of the obstacles farmers in doing business, such as the absence of assistance in the form of beef cattle going.

b. Facilitating commercial and market-oriented farming

Market orientation of group members has a low performance because farmers do not have a decision to sell their livestock are oriented to obtain high prices and profits, and do not know the high level of consumer demand on the holiday so that high prices can be obtained.

c. Facilitating the application of technology (materials, tools, ways) Farming by members in accordance with the activity plan Members of the group's performance felt the absence of complete technology as a means of beef cattle business is still low. However, the members considered this attribute to be less critical because they considered that the current beef cattle cultivation activities could be done traditionally and did not require technology. In the future, the members hope that the management can try a complete sapronak to help smooth activities and through technology can process waste and add value.

The attributes that are in quadrant IV describe the attributes of the aspects of group ability as less important attributes but actually high performance. The attributes included in quadrant IV can be seen, namely: 
a. Establish cooperation with information sources in the teaching and learning process, both from fellow members, advisory agencies and related parties

b. Active in the teaching-learning process, including bringing in and consulting agricultural extension institutions, and other sources of information

The two attributes above are felt by respondents to be less important but in actual conditions, the group carries out the performance well. In the assessment of the ability to bring sources of information in the teaching and learning process is very good, but members do not really consider this attribute to be prioritized.

\section{Customer Satisfaction Index (CSI)}

The results of the Customer Satisfaction Index analysis show the extent of the level of member satisfaction with the implementation of aspects of group capacity development carried out by the organization's management. CSI analysis results can be seen in Table 31. Based on CSI calculation results in the table, it appears that the value of the Customer Satisfaction Index is 34 percent or 0.34 interval. If this value is based on the consumer satisfaction index, the CSI value that reaches 0.34 is in the interval $0.00-0.34$ so it can be said that in general, the member satisfaction index for the attributes tested is on the dissatisfied criteria which means the performance of livestock farmer groups in the beginner ability class must continue to improve its performance so that member satisfaction with the attributes of aspects of the group's ability to develop close to 100 percent or at a very satisfying level.

Table 31. CSI calculation of beginner ability classes

\begin{tabular}{|c|c|c|c|c|c|}
\hline No. & Attribute & $\begin{array}{c}\text { Mean } \\
\text { Importance } \\
\text { Score (MIS) }\end{array}$ & $\begin{array}{l}\text { Weight } \\
\text { Factors } \\
(\text { WF })\end{array}$ & $\begin{array}{c}\text { Average } \\
\text { Level of } \\
\text { Performance }\end{array}$ & $\begin{array}{l}\text { Weight } \\
\text { Score }\end{array}$ \\
\hline 1 & Hold regular meetings & 4,20 & 4,96 & 1,60 & 0,08 \\
\hline 2 & Prepare RDK and RDKK work plans & 4,50 & 5,32 & 2,68 & 0,14 \\
\hline 3 & $\begin{array}{l}\text { Facilitating joint business activities in the upstream to } \\
\text { downstream sectors }\end{array}$ & 3,47 & 4,10 & 1,30 & 0,05 \\
\hline 4 & Facilitating commercial and market-oriented farming & 3,43 & 4,05 & 1,80 & 0,07 \\
\hline 5 & $\begin{array}{c}\text { Streamlining the process of identifying needs and } \\
\text { problems in farming }\end{array}$ & 4,25 & 5,02 & 1,53 & 0,08 \\
\hline 6 & Improve the ability of members & 4,43 & 5,24 & 1,50 & 0,08 \\
\hline 7 & Development of creativity and member initiatives & 4,25 & 5,02 & 1,15 & 0,06 \\
\hline 8 & $\begin{array}{l}\text { Developing the ability of members to produce } \\
\text { technology }\end{array}$ & 4,73 & 5,59 & 1,47 & 0,08 \\
\hline 9 & Foster discipline and motivation of members; & 4,63 & 5,47 & 2,00 & 0,11 \\
\hline 10 & $\begin{array}{c}\text { Conducting meetings and learning in a conducive and } \\
\text { orderly manner }\end{array}$ & 4,25 & 5,02 & 1,15 & 0,06 \\
\hline 11 & $\begin{array}{l}\text { Establish cooperation with information sources in the } \\
\text { teaching and learning process, both from fellow } \\
\text { members, advisory agencies and related parties }\end{array}$ & 4,10 & 4,85 & 1,93 & 0,09 \\
\hline 12 & $\begin{array}{l}\text { Active in the teaching-learning process, including } \\
\text { bringing in and consulting agricultural extension } \\
\text { institutions, and other sources of information }\end{array}$ & 4,17 & 4,93 & 1,90 & 0,09 \\
\hline 13 & $\begin{array}{l}\text { Formulating collective agreements, in solving problems } \\
\text { and carrying out various activities }\end{array}$ & 4,57 & 5,40 & 1,10 & 0,06 \\
\hline 14 & $\begin{array}{c}\text { Organize and carry out the division of tasks / work } \\
\text { between members in accordance with mutual agreement }\end{array}$ & 4,25 & 5,02 & 1,53 & 0,08 \\
\hline 15 & $\begin{array}{l}\text { Develop discipline and a sense of responsibility among } \\
\text { members }\end{array}$ & 4,25 & 5,02 & 1,44 & 0,07 \\
\hline 16 & $\begin{array}{l}\text { Implement deliberations to reach an agreement that is } \\
\text { beneficial for members }\end{array}$ & 4,57 & 5,40 & 1,20 & 0,06 \\
\hline 17 & $\begin{array}{l}\text { Establish cooperation / business partnerships with } \\
\text { providers of production, processing, marketing of } \\
\text { results and / or capital }\end{array}$ & 4,20 & 4,96 & 1,85 & 0,09 \\
\hline 18 & $\begin{array}{l}\text { Facilitating the application of technology (materials, } \\
\text { tools, ways) Farming by members in accordance with } \\
\text { the activity plan }\end{array}$ & 3,63 & 4,29 & 1,70 & 0,07 \\
\hline 19 & Administrative management is good and right & 4,50 & 5,32 & 3,40 & 0,18 \\
\hline 20 & Ability to plan the processing and marketing of results & 4,23 & 5,00 & 1,70 & 0,08 \\
\hline & Total & 84,61 & 100 & 33,93 & 1,70 \\
\hline & Average & 4,23 & 5 & 1,70 & 0,09 \\
\hline \multicolumn{5}{|c|}{ CSI } & 0,34 \\
\hline
\end{tabular}


Through the IPA analysis, it can be seen the CSI results which state the level of member satisfaction is at an interval of 34 percent. For the satisfaction measure, the value is not maximal so that the farmer groups of beginner ability classes must continue to improve their performance. The attributes that should be a priority for performance improvement are in quadrant I, where those attributes are not the optimal performance and must continue to be improved. Meanwhile, the performance attributes in quadrant II must be maintained so that in its development, it is expected to increase the value of CSI until the criteria are very satisfied.

\section{CONCLUSION}

Based on the results of the study concluded that the performance of the implementation of the ability of beginner groups based on IPA analysis showed that there were still many attributes in quadrant I to be a top priority for improvement. Through the IPA analysis, it can be seen the CSI results which state the level of member satisfaction is at an interval of 34 percent or 0.34 . This value is not optimal or in the category of "not satisfied" so that the livestock farmer groups must continue to improve their performance. Meanwhile, the performance attributes in quadrant II must be maintained so that in its development, it is expected to increase the value of CSI.

\section{REFERENCES}

[1] Sirajuddin, S.N., A. Asnawi, I.Rasyid, A.Mangalisu, Masnur. 2016. Competitiveness of Beef Cattle Fattening in Kulo Subdistrict, Sidrap District South Sulawesi. Advances in Environmental Biology Journals. Vol. 10. No.1. Page 171-175.

[2] Anantanyu, S. 2011. Kelembagaan petani: Peran dan strategi pengembangan kapasitasnya. Sepa. VII (2): $109-190$.

[3] Prasetyo,T., D. Maharso, dan C. Setiani. 2010. Tinjauan tentang populasi sapi potong dan kontribusinya terhadap kebutuhan daging di Jawa Tengah. Sains Peternakan. Vol. 8(1)32-39.

[4] Abdullah, A., J. Mustabi, A. Amrawaty, A. Asnawi, and S.Nurlaelah. 2018. The role of farmer group on development of beef cattle business. IOP Conference Series: Earth and Environmental Science.

[5] Amrawaty, A., I. M. Saleh, Jamila. Relationship of Farmer's Characteristics with Adapted Choice in Facing of the Lack Feeding in Barru Regency. AENSI Journals Advances in Environmental Biology ISSN-1995-0756 EISSN-1998-1066. Advances in Environmental Biology, 11(12) December 2017, Pages: 21-25

[6] Rasyid, T.G., S Hasan, S.Rasjid and S.N Sirajuddin. Accessibility goat livestock cooperation with the government, merchant banking and collecting in Majene regency, West Sulawesi Province. American-Eurasian Journal of Sustainable Agriculture ISSN: 1995-0748, EISSN: 1998-1074 2015, volume (9), issue(7): pages(13-18)

[7] Rasyid, T.G., S Hasan, S.Rasjid and S.N Sirajuddin. Development model of goat farming business base on productive economy in Majene regency, West Sulawesi, Indonesia. American-Eurasian Journal of Sustainable Agriculture (Vol. 10, Issue 3)

[8] Lestari, V.S., S.N. Sirajuddin, K.Kasyim. Perception of Beef Cattle Farmers toward Biosecurity Practices. AENSI Journals ces in Environmental Biology ISSN-1995-0756 EISSN-1998-1066. Volume 9 (24) November 2015, Pages: 450-452

[9] Rangkuti, F. 2006. Measuring Costumer Satisfaction. PT. Gramedia Pustaka Utama. Jakarta. 